\title{
Proficiency of Post-harvest Treatments in Maintaining Sensory and Organoleptic Quality Attributes of Rambutan (Nephelium lappaceum L.) during Ambient Storage
}

\author{
Manjunath J. Shetty ${ }^{1 *}$, P.R. Geethalekshmi ${ }^{2}$, C. Mini ${ }^{2}$ and Thushara T. Chandran ${ }^{2}$ \\ ${ }^{1}$ Department of Post-Harvest Technology, College of Horticulture, Bengaluru, \\ UHS (B), Karnataka, India \\ ${ }^{2}$ Department of Post-Harvest Technology, College of Agriculture, Vellayani, \\ $K A U$, Kerala, India \\ *Corresponding author
}

\section{A B S T R A C T}

\begin{tabular}{|l|}
\hline K e y w o r d s \\
Rambutan, Browning, \\
spinterns, \\
$\begin{array}{l}\text { Sulphitation, Scores, } \\
\text { Ozonization, Paraffin }\end{array}$ \\
\hline Article Info \\
\hline $\begin{array}{l}\text { Accepted: } \\
\text { 14 December } 2017 \\
\text { Available Online: } \\
\text { 10 January } 2018\end{array}$ \\
\hline
\end{tabular}

\section{Introduction}

Rambutan (Nephelium lappaceum L.) is an important exotic fruit, indigenous to Southeast Asia, including Thailand, Malaysia, and Indonesia (Lam et al., 1987). It is a good source of vitamin $\mathrm{C}$, calcium and provides fairly a good amount of niacin, iron, phosphorus, carbohydrate, protein, and fibre. As a non-climacteric fruit, rambutan must be harvested at the peak of maturity as further ripening does not continue after harvest
(O'Hare, 1995; Wall et al., 2011). The most attractive and distinctive feature of rambutan fruit is its bright red or yellow peel and spinterns (Landrigan et al., 1996). The flavour of the juicy aril is a blend of sweet and sour taste (Lam et al., 1987). Farmers in many parts of Kottayam and Pathanamthitta in Central Travancore have taken rambutan cultivation to cater the demand of fruits from traders in Tamil Nadu and Karnataka (Kuttoor, 2009). However, the presence of the hair like spinterns makes the fruit very 
perishable. Spinterns desiccate easily and turn brown or black, thereby limiting shelf life and reducing commercial value of the fruit. However, browning and decay occur within 1 to 3 days after harvest and storage. Numerous pre-treatments and processes have been developed to reduce decay and browning. Browning due to high transpiration, high respiration rate and decay are the main causes for quality deterioration and postharvest loss of rambutan. Water loss also induces degradation of nutritional value and imposes stress that increases respiration and ethylene production. Suitable postharvest handling practices can enhance the shelf life by preserving its nutritional quality and there by extending the availability for domestic and distant market. Objectives of pre-treatments are reduction or elimination of enzymes induce browning and microorganisms from fruits and guarantee it for consumption (Bachelli et al., 2013). Thus the objective of present investigation was to study the efficacy of pre-treatments in reducing browning of fresh rambutans.

\section{Materials and Methods}

\section{Materials}

The investigation was carried out in the PG laboratory of Post-Harvest Technology, College of Agriculture, Vellayani, Kerala Agricultural University. The investigation was carried out with three types of treatments viz., Waxing (1\%), Sulphitation (350 ppm) for 5 minutes and Ozonisation (2 ppm) for 5 minutes. Rambutan fruits of optimum maturity and uniform red skin colour were procured from the identified homesteads of Thiruvananthapuram districts.

\section{Methods}

Waxing was done using $1 \%$ paraffin wax and sulphitation was carried out by dissolving potassium metabisulphite (KMS) in water limiting the $\mathrm{SO}_{2}$ concentration to $350 \mathrm{ppm}$ while ozonizer (Plate 1) was used for ozonization of rambutan fruits.

The pre-treated fruits were spread out to remove excess surface moisture and stored at room temperature. Effectiveness of pretreatments were analyzed based on browning score, visual parameters (general appearance) and internal fruit quality parameters daily till the end of shelf by conducting a sensory evaluation trial with semi trained panel of 30 members.

\section{Browning score}

A score card proposed by Follet and Sanxter (2000) at five point hedonic scale was used for assessing the browning of fruits with following scores. $10 \%$ spinterns darkened $=1$, $25 \%$ spinterns darkened $=2,50 \%$ spinterns darkened $=3$, All spinterns and $50 \%$ or less of the pericarp surface area distinctly darkened $=4$, All spinterns and $50 \%$ or more of the pericarp surface area distinctly darkened $=5$.

\section{General appearance}

A nine point hedonic scale score card proposed by Brown and Wilson (1988) was used for assessing the visual appearance.

\section{Internal fruit quality}

\section{Taste}

Taste of fruit was subjectively rated using a scale of 1, 2, 3, 4 and 5 as Excellent, Very good, Good, Fair, Poor respectively.

\section{Flavour}

Flavour of fruit was rated using a scale score card proposed by Brown and Wilson (1988) was used for assessing with following scores, 
Excellent - 1, Very good - 2, Good - 3, Fair 4 , Poor -5 .

\section{Pulp browning}

A five point scale score card was used for assessing the pulp browning with following scores, No browning - 1, 5\% browning - 2 , $10 \%$ browning $-3,25 \%$ browning $-4,50 \%$ browning -5 .

\section{Statistical design}

Effects of different treatments on browning score, general appearance (consumer acceptance) and organoleptic parameters viz. taste, flavour and pulp browning were statistically analyzed using Kruskall-Wallis test (chi-square value) and ranked (Shamrez et al., 2013) and found that treatments differed significantly.

\section{Results and Discussion}

Colour of rambutan fruits is the key of success for the better market value and browning of pericarp is a major challenge. Browning is due to enzymatic reaction which is influenced by concentration of oxygen and polyphenol oxidase (PPO) enzyme. Inhibition of any one

Plate.1 Ozonizer

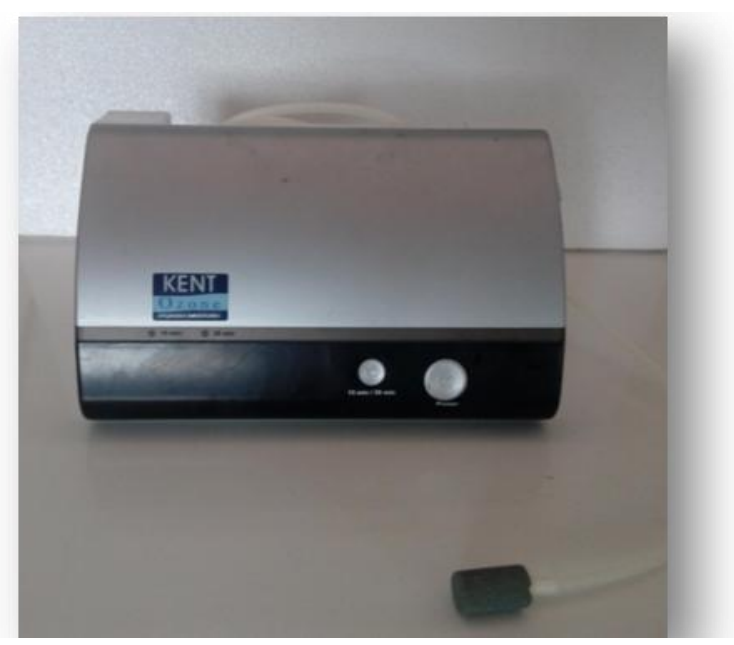

of the essential factors reduces browning of pericarp. $2 \mathrm{ppm}$ ozonization recorded minimum browning with scores of 3.86 and 4.10 and the highest mean score of 4.90 and 5.00 for control (without any pre-treatment) after $4^{\text {th }}$ and $5^{\text {th }}$ day of storage respectively (Table 1).

Similar results were reported by Barth et al., (1995) in blackberries and Perez et al., (1999) in strawberries.

General appearance is important criteria for consumer acceptability of rambutan fruits. Any change in fruit colour might be recognized as senescence or damaged which reduces its marketable value (Nunes et al., 2009). Rambutan fruits treated with $2 \mathrm{ppm}$ ozonization recorded the highest mean score of 4.83 with the rank one and the lowest mean score of 1.56 was obtained for control after the end of shelf life (Table 2). Ozonization helped in improving the colour of fruits during storage were reported by Hernandez et al., (2004) in grapes, Zambre et al., (2010) and Alexandre et al., (2012) in strawberries. Figure 1 and 2 clearly depicts the improved colour retention during storage enhanced overall acceptability after 5 days of storage.

Plate.2 Ozonization process

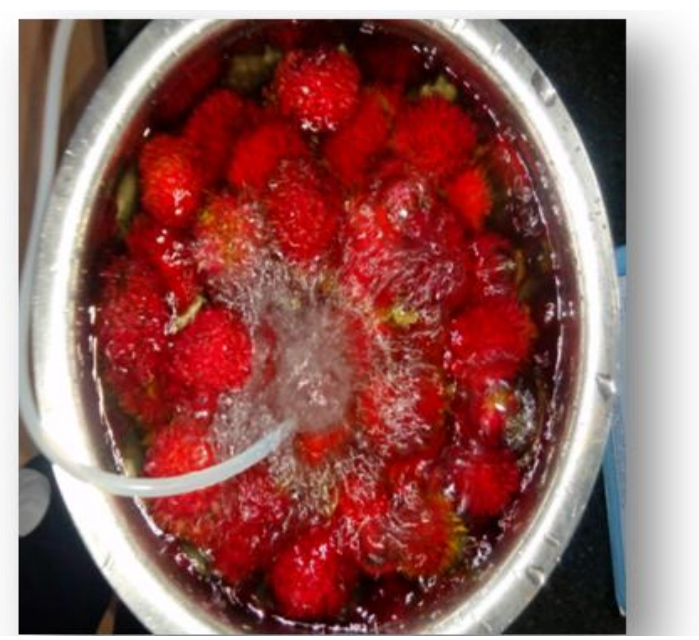


Plate.3 Ozonated fruits in comparison with control

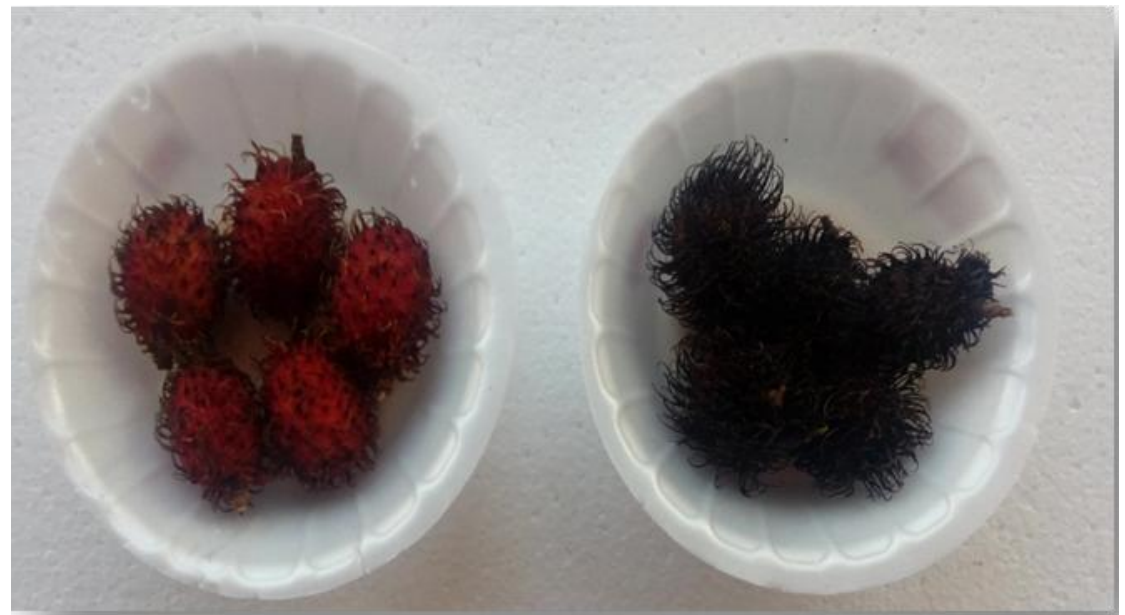

Fig.1 Effect of pre-treatments on browning score of rambutan fruits $\left(\mathrm{T}_{3}\right.$-ozonization and $\mathrm{T}_{4}$-control)

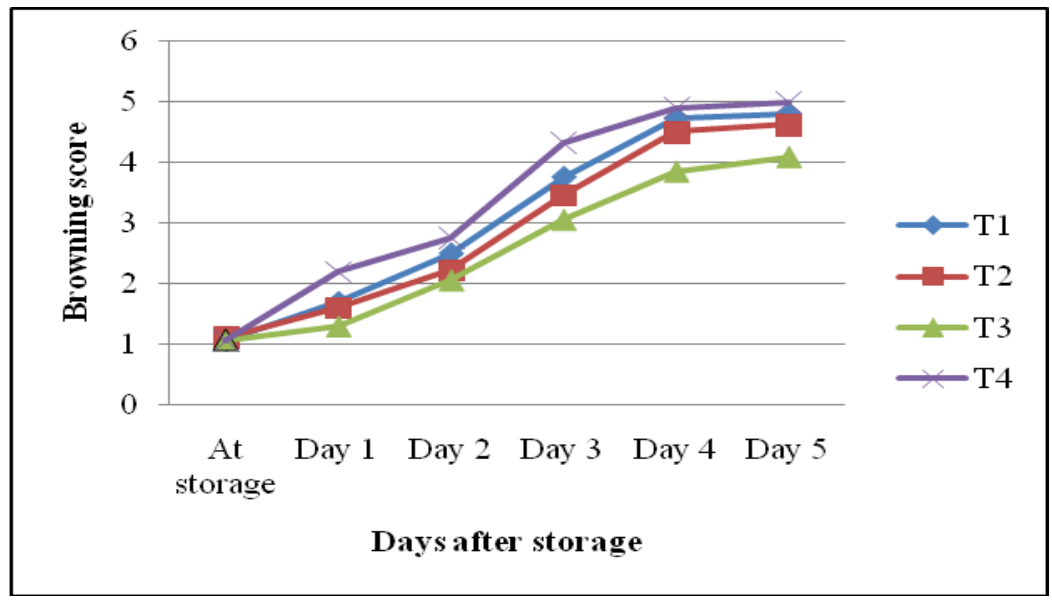

Fig.2 Effect of pre-treatments on general appearance of rambutan fruits $\left(\mathrm{T}_{3}\right.$-ozonization and $\mathrm{T}_{4}$-control)

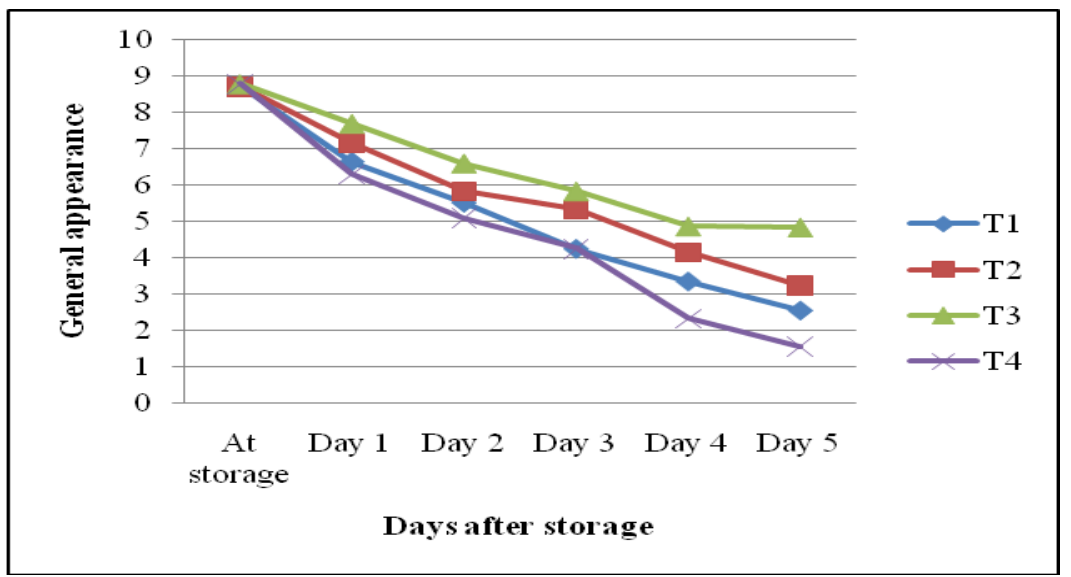


Table.1 Effect of pretreatments on browning score of rambutan fruits

\begin{tabular}{|c|c|c|c|c|c|c|c|c|c|c|c|c|}
\hline \multirow{3}{*}{ Treatments } & \multicolumn{12}{|c|}{ Days after storage } \\
\hline & \multicolumn{2}{|c|}{ At storage } & \multicolumn{2}{|c|}{1} & \multicolumn{2}{|c|}{2} & \multicolumn{2}{|c|}{3} & \multicolumn{2}{|c|}{4} & \multicolumn{2}{|c|}{5} \\
\hline & Rank & $\begin{array}{l}\text { Mean } \\
\text { score }\end{array}$ & Rank & $\begin{array}{c}\text { Mean } \\
\text { score }\end{array}$ & Rank & $\begin{array}{l}\text { Mean } \\
\text { score }\end{array}$ & Rank & $\begin{array}{l}\text { Mean } \\
\text { score }\end{array}$ & Rank & $\begin{array}{l}\text { Mean } \\
\text { score }\end{array}$ & Rank & $\begin{array}{c}\text { Mean } \\
\text { score }\end{array}$ \\
\hline Paraffin wax $\left(\mathrm{T}_{1}\right)$ & 1 & 1.06 & 3 & 1.70 & 3 & 2.50 & 3 & 3.76 & 3 & 4.73 & 3 & 4.80 \\
\hline Sulphitation $\left(\mathrm{T}_{2}\right)$ & 2 & 1.10 & 2 & 1.60 & 2 & 2.23 & 2 & 3.46 & 2 & 4.50 & 2 & 4.63 \\
\hline Ozonization $\left(\mathrm{T}_{3}\right)$ & 1 & 1.06 & 1 & 1.30 & 1 & 2.06 & 1 & 3.06 & 1 & 3.86 & 1 & 4.10 \\
\hline Control $\left(\mathrm{T}_{4}\right)$ & 1 & 1.06 & 4 & 2.20 & 4 & 2.76 & 4 & 4.33 & 4 & 4.90 & 4 & 5.00 \\
\hline KW value & \multicolumn{2}{|c|}{$14.45^{* *}$} & \multicolumn{2}{|c|}{$17.10^{* *}$} & \multicolumn{2}{|c|}{$14.75^{* *}$} & \multicolumn{2}{|c|}{$17.67^{* *}$} & \multicolumn{2}{|c|}{$14.05^{* *}$} & \multicolumn{2}{|c|}{$21.65^{* *}$} \\
\hline$\chi^{2}(0.05)$ & \multicolumn{12}{|c|}{7.81} \\
\hline
\end{tabular}

Scores:

$10 \%$ spinterns darkened-1

$25 \%$ spinterns darkened-2

$50 \%$ spinterns darkened- 3

All spinterns and $50 \%$ or less of the pericarp surface area distinctly darkened- 4

All spinterns and $50 \%$ or more of the pericarp surface area distinctly darkened-5

Table.2 Effect of pretreatments on general appearance of rambutan fruits

\begin{tabular}{|c|c|c|c|c|c|c|c|c|c|c|c|c|}
\hline \multirow{3}{*}{ Treatments } & \multicolumn{12}{|c|}{ Days after storage } \\
\hline & \multicolumn{2}{|c|}{ At storage } & \multicolumn{2}{|c|}{1} & \multicolumn{2}{|c|}{2} & \multicolumn{2}{|c|}{3} & \multicolumn{2}{|c|}{4} & \multicolumn{2}{|c|}{5} \\
\hline & Rank & $\begin{array}{c}\text { Mean } \\
\text { score }\end{array}$ & Rank & $\begin{array}{l}\text { Mean } \\
\text { score }\end{array}$ & Rank & $\begin{array}{l}\text { Mean } \\
\text { score }\end{array}$ & Rank & $\begin{array}{l}\text { Mean } \\
\text { score }\end{array}$ & Rank & $\begin{array}{l}\text { Mean } \\
\text { score }\end{array}$ & Rank & $\begin{array}{l}\text { Mean } \\
\text { score }\end{array}$ \\
\hline Paraffin wax $\left(\mathrm{T}_{1}\right)$ & 2 & 8.76 & 3 & 6.66 & 3 & 5.53 & 3 & 4.26 & 3 & 3.36 & 2 & 2.56 \\
\hline Sulphitation $\left(\mathrm{T}_{2}\right)$ & 3 & 8.73 & 2 & 7.16 & 2 & 5.83 & 2 & 5.33 & 2 & 4.16 & 2 & 3.23 \\
\hline Ozonization $\left(\mathrm{T}_{3}\right)$ & 1 & 8.80 & 1 & 7.70 & 1 & 6.60 & 1 & 5.83 & 1 & 4.86 & 1 & 4.83 \\
\hline Control $\left(\mathrm{T}_{4}\right)$ & 1 & 8.80 & 4 & 6.30 & 4 & 5.10 & 4 & 4.26 & 4 & 2.33 & 4 & 1.56 \\
\hline KW value & \multicolumn{2}{|c|}{$24.07^{* *}$} & \multicolumn{2}{|c|}{$28.96^{* *}$} & \multicolumn{2}{|c|}{$32.03^{* *}$} & \multicolumn{2}{|c|}{$30.71^{* *}$} & \multicolumn{2}{|c|}{$33.17^{* *}$} & \multicolumn{2}{|c|}{$36.79^{* *}$} \\
\hline$\chi^{2}(0.05)$ & \multicolumn{12}{|c|}{7.81} \\
\hline
\end{tabular}

Scores:

Like extremely-9 Like very much-8

Dislike slightly-4 Dislike moderately-3

** Significant
Like moderately-7

Dislike very much-2
Like slightly-6 Neither like nor dislike-5

Dislike extremely-1 
Table.3 Effect of pretreatments on taste of rambutan fruits

\begin{tabular}{|c|c|c|c|c|c|c|c|c|c|c|c|c|}
\hline \multirow{3}{*}{ Treatments } & \multicolumn{12}{|c|}{ Days after storage } \\
\hline & \multicolumn{2}{|c|}{ At storage } & \multicolumn{2}{|r|}{1} & \multicolumn{2}{|c|}{2} & \multicolumn{2}{|c|}{3} & \multicolumn{2}{|c|}{4} & \multicolumn{2}{|r|}{5} \\
\hline & Rank & Mean score & Rank & Mean score & Rank & Mean score & Rank & Mean score & Rank & Mean score & Rank & Mean score \\
\hline Paraffin wax $\left(\mathrm{T}_{1}\right)$ & 1 & 1.03 & 2 & 1.10 & 2 & 1.16 & 3 & 1.53 & 3 & 1.83 & 3 & 2.96 \\
\hline Sulphitation $\left(T_{2}\right)$ & 1 & 1.03 & 2 & 1.10 & 3 & 1.20 & 2 & 1.46 & 2 & 1.76 & 2 & 2.80 \\
\hline Ozonization $\left(\mathrm{T}_{3}\right)$ & 1 & 1.03 & 1 & 1.06 & 1 & 1.10 & 1 & 1.30 & 1 & 1.66 & 1 & 2.43 \\
\hline Control $\left(\mathrm{T}_{4}\right)$ & 1 & 1.03 & 3 & 1.20 & 4 & 1.36 & 4 & 1.86 & 4 & 2.63 & 4 & 3.60 \\
\hline KW value & \multicolumn{2}{|r|}{--} & \multicolumn{2}{|c|}{$24.13^{* *}$} & \multicolumn{2}{|c|}{$24.41^{* *}$} & \multicolumn{2}{|c|}{$25.06^{* *}$} & \multicolumn{2}{|c|}{$28.78^{* *}$} & \multicolumn{2}{|c|}{$28.36^{* *}$} \\
\hline$\chi^{2}(0.05)$ & & & & & & & & & & & & \\
\hline
\end{tabular}

Scores:

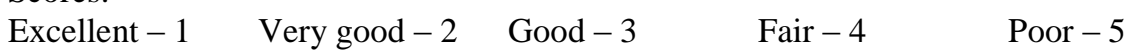

Table.4 Effect of pretreatments on flavour of rambutan fruits

\begin{tabular}{|c|c|c|c|c|c|c|c|c|c|c|c|c|}
\hline \multirow{3}{*}{ Treatments } & \multicolumn{12}{|c|}{ Days after storage } \\
\hline & \multicolumn{2}{|c|}{ At storage } & \multicolumn{2}{|r|}{1} & \multicolumn{2}{|c|}{2} & \multicolumn{2}{|c|}{3} & \multicolumn{2}{|c|}{4} & \multicolumn{2}{|c|}{5} \\
\hline & Rank & Mean score & Rank & Mean score & Rank & Mean score & Rank & Mean score & Rank & Mean score & Rank & Mean score \\
\hline Paraffin wax $\left(T_{1}\right)$ & 1 & 1.06 & 3 & 1.50 & 3 & 2.30 & 3 & 2.70 & 3 & 3.43 & 3 & 4.06 \\
\hline Sulphitation $\left(T_{2}\right)$ & 1 & 1.06 & 2 & 1.33 & 2 & 1.76 & 2 & 2.26 & 2 & 2.76 & 2 & 3.26 \\
\hline Ozonization $\left(\mathrm{T}_{3}\right)$ & 1 & 1.06 & 1 & 1.20 & 1 & 1.63 & 1 & 1.86 & 1 & 2.13 & 1 & 2.96 \\
\hline Control $\left(\mathrm{T}_{4}\right)$ & 1 & 1.06 & 4 & 1.70 & 4 & 2.40 & 4 & 3.36 & 4 & 4.20 & 4 & 4.80 \\
\hline KW value & \multicolumn{2}{|r|}{--} & \multicolumn{2}{|c|}{$25.38^{* *}$} & \multicolumn{2}{|c|}{$26.20^{* *}$} & \multicolumn{2}{|c|}{$28.47^{* *}$} & \multicolumn{2}{|c|}{$32.13^{* *}$} & \multicolumn{2}{|c|}{$30.92^{* *}$} \\
\hline$\chi^{2}(0.05)$ & & & & & & & 81 & & & & & \\
\hline
\end{tabular}

Scores:

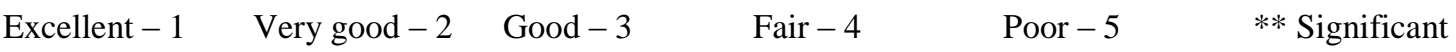

Table.5 Effect of pretreatments on pulp browning of rambutan fruits

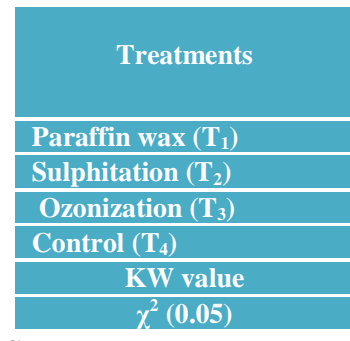

Scores:

No browning -1

\begin{tabular}{|c|c|c|c|c|c|c|c|c|c|c|c|}
\hline Rank & Mean score & Rank & Mean score & Rank & Mean score & Rank & Mean score & Rank & Mean score & Rank & Mean score \\
\hline 1 & 1.03 & 2 & 1.33 & 3 & 1.60 & 3 & 2.63 & 3 & 3.70 & 3 & 4.50 \\
\hline 1 & 1.03 & 1 & 1.03 & 2 & 1.56 & 2 & 2.43 & 2 & 3.10 & 2 & 3.46 \\
\hline 1 & 1.03 & 1 & 1.03 & 1 & 1.40 & 1 & 1.96 & 1 & 2.56 & 1 & 2.70 \\
\hline 1 & 1.03 & 3 & 1.60 & 4 & 2.20 & 4 & 3.43 & 4 & 4.23 & 4 & 4.83 \\
\hline \multicolumn{2}{|r|}{--} & \multicolumn{2}{|c|}{$24.37^{* *}$} & \multicolumn{2}{|c|}{$26.62^{* *}$} & \multicolumn{2}{|c|}{$28.51^{* *}$} & \multirow{2}{*}{\multicolumn{2}{|c|}{$31.82^{* *}$}} & \multirow{2}{*}{\multicolumn{2}{|c|}{$32.85^{* *}$}} \\
\hline & & & & & & & & & & & \\
\hline
\end{tabular}

$5 \%$ browning $-210 \%$ browning $-3 \quad 25 \%$ browning -4

$50 \%$ browning -5

** Significant 
Taste of the fruits mainly depends on the type of treatments and its concentration when stored at room temperature. Rambutan fruits treated with 2 ppm ozonization and stored at room temperature recorded rank 1 with the mean score of 2.43 after $5^{\text {th }}$ day of storage. Sulphitation 350 ppm treated fruits scored second ranking for taste and the lowest rank was obtained for untreated fruits at the end of shelf life (Table 3 ).

Flavour is an important parameter for consumer acceptance. Fruits pre-treated with ozone recorded highest ranking with the scores of 2.96 at the end of shelf life (Table 4).

The fruits without any pre-treatment (control) recorded the lowest ranking throughout the storage period. $2 \mathrm{ppm}$ ozonated fruits recorded first ranking with minimum pulp browning scores of 2.56 and 2.70 after $4^{\text {th }}$ and $5^{\text {th }}$ day of storage (Table 5).

The highest browning score was for without any pre-treatment as 4.83 after $5^{\text {th }}$ day of storage. Browning of aril is mainly attributed to increase in water loss due to respiration, transpiration of fruits and also due to enzymatic reaction. Rambutan fruits with ozone recorded the highest score for taste and flavor with lowest pulp browning which lead to better internal fruit quality.

This result is supported by different research reports and stating that ozonization improved taste (Barboni et al., 2010; Eggink et al., 2012; Piombino et al., 2013), flavour (Zhang et al., 2005 and Olmez and Akbas, 2009) and also reduced pulp browning (Beltran et al., 2005; El-Saedy et al., 2011 and Rodoni et al., 2011).

\section{Acknowledgement}

Thankful to Kerala Agricultural University for making available of facilities for research and Dr. Vijayaraghavakumar (Agricultural Statistics) for useful suggestions at the time of statistical analysis. Sincere gratitude to teaching and non-teaching personnel of COA, Vellayani

\section{References}

Alexandre, E. M. C., Brandao, T. R. S. and Silva, C. L. M. 2012. Efficacy of no thermal technologies and sanitizer solutions on microbial load reduction and quality retention of strawberries. J. Food Engg. 108: 417-426.

Bachelli, M. L. B., Amaral, R. D. A. and Benedetti, B. C. 2013. Alternative sanitization methods for minimally processed lettuce in comparison to sodium hypochlorite. Braz. J. Microbiol. 44(3): 673-678.

Barboni, T., Cannac, M. and Chiromente, N. 2010. Effect of cold storage and ozone treatment on physiochemical parameters, soluble sugars and organic acids in Actinidia deliciosa. Food Chem. 121: 946951.

Barth, M. M., Zhou, C., Mercier, J. and Payne, F. A. 1995. Ozone storage effects on anthocyanin content and fungal growth in blackberries. J. Food Sci. 60(6): 1286-1288.

Beltran, D., Selma, M. V., Marin, A. and Gil, M. I. 2005. Ozonated water extends the shelf life of fresh-cut lettuce. J. Agric. Food Chem. 53(14): 5654-5663.

Brown, B. I. and Wilson, P. R. 1988. Exploratory study of postharvest treatments on rambutan (Nephelium lappaceum L.) 1986/1987 season. Rare Fruit Council Aust. Newsl. 48: 16-18.

Eggink, P. M., Maliepaard, C., Tikunov, Y., Haanstra, J. P. W., Bovy, A. G. and Visser, R. G. F. 2012. A taste of sweet pepper: volatile and non-volatile chemical composition of fresh sweet pepper (Capsicum annuum) in relation to sensory evaluation of taste. Food Chem. 132: 301310.

El-Saedy, D. O., Ansary, N. I. and Naggar. 2011. Postharvest ozone and hot water treatments increase storage life of kent mango fruits at 
two maturity stages, Alexandria J. Agric. Res. 56: 521-528.

Follet, P. and Sanxter, S. S. 2000. Comparison of rambutan quality after hot forced air and irradiation quarantine treatments. Hortic. Sci. 35: 1315-1318.

Hernandes-Arenas, M., Nieto-Angel., MartinezDamian., Teliz-Ortiz. D., Diaz, C. N., and Baustista-Martinez, N. 2012. Rambutan postharvest storage in two temperatures and modified atmospheres. Int. J. Trop. fruits. 37(7): 542-546.

Kuttoor, R. 2009. Farmers taking to rambutan cultivation. The Hindu, 28 June. 2009, p. 3.

Lam, P. F., Kosiyachinda, S., Lizada, M. C. C., Mendonza, D. B., Prabawati, Jr. S. and Lee, S. K. 1987. Postharvest physiology and storage of rambutan. In: Lam, P. F and Kosiyachinda, S. (eds), Rambutan Fruit Development, Postharvest Physiology and Marketing in ASEAN. ASEAN Food Handling Bureau, Kaula Lumpur, pp. 3950.

Landrigan, M., Morris, S. C. and McGlasson, W.B. 1996. Postharvest Browning of rambutan is a consequence of water loss. $J$. Amer. Soc. Hortic. Sci. 121(4): 730-734.

Nunes, M. C. N., Emond, J. P., Rauth, M., Dea, S. and Chau, K. V. 2009. Environmental conditions enquired during typical consumer retail display affect fruit and vegetable quality and waste. Postharvest Biol. Technol. 51: 232-241.

O'Hare, T. J. 1995. Postharvest physiology and storage of rambutan. Postharvest Biol.Technol. 6: 189-199.

Olmez, H. and Akbas, M. Y. 2009. Optimization of ozone treatment of fresh-cut green leaf lettuce. J. Food Eng. 90: 487-494.

Perez, G. A, Sanz, C, Rios, J. J, Olias, R. and Olias, J. M. 1999. Effects of ozone treatment on postharvest strawberry quality. J. Agric. Food Chem. 47(4): 1652-1656.

Piombino, P., Sinesio, F., Moneta, E., Cammareri, M., Genovese, A., Lisanti, M. T. 2013. Investigating physicochemical, volatile and sensory parameters playing a positive or a negative role on tomato liking. Food Res. Int. 50: 409-419.

Rodoni, N., Casadei, A., Concellon, A. R., Chaves Alicia, A. R. and Vicente. 2011. Effect of short-term ozone treatments on tomato (Solanum lycopersicum L.) fruit quality and cell wall degradation, J. Agric. Food Chem. 58: 594-599.

Shamrez, A., Shukla, R. N., Mishra, A. 2013. Study on drying and quality characteristics of tray and microwave dried guava slices. Intl. J. Sci. Eng. Technol. 3(4): 2348-4098.

Wall, M. M., Sivakumar, D. and Korsten, L. 2011. Rambutan (Nephelium lappaceum). In: Yahia E. M. (ed.), Postharvest. Biol. Technol. Trop. Subtropical Fruits. Woodhead Publications, U.K. 312-333.

Zambre, S. S., Venkatesh, K. V. and Shah, N. G. 2010. Tomato redness for assessing ozone treatment to extend the shelf life. J. Food Engg. 71: 443-446.

Zhang, L., Lu, Z., Yu, Z. and Gao, X. 2005. Preservation of fresh-cut fruits by treatment of ozonated water. Food Control. 16: 279283.

\section{How to cite this article:}

Manjunath J. Shetty, P.R. Geethalekshmi, C. Mini and Thushara T. Chandran. 2018. Proficiency of Post-harvest Treatments in Maintaining Sensory and Organoleptic Quality Attributes of Rambutan (Nephelium lappaceum L.) during Ambient Storage. Int.J.Curr.Microbiol.App.Sci. 7(01): 1676-1683. doi: https://doi.org/10.20546/ijcmas.2018.701.203 